\title{
Preparation of Necrotic Enteritis Vaccine for Turkey
}

\author{
Elham El-Sergany, El-Helw Hamed*, Hala El-Sawy, Taha Medhat, Abdalla Yasser and El-Meneisy Alaa \\ Anaerobic Bacterial Vaccine Research Department, Veterinary Serum and Vaccine Research Institute, Abbasia, Cairo, Egypt
}

"Corresponding author’s Email: hamedelhelw@ hotmail.com; ORCID: 0000-0003-2851-9632

Received: 14 May 2019

Accepted: 12 June 2019

\begin{abstract}
Clostridium perfringens is the most important cause of enteritis in domestic animals, in chicken and turkey it well known as pathogen responsible for necrotic enteritis; hepatitis, and cholecystitis. The disease in turkey characterize by either severe form with high rate of mortalities or subclinical form of reduce growth rate and increase condemnation rate. The major factor responsible for pathogenicity of Clostridium perfringens was alpha toxin. The aim of present study was to prepare of Clostridium perfringens alpha Toxoid vaccine for controlling the necrotic enteritis disease. The vaccine was prepared at different doses depend on lethality of toxin (24, 48 and 96 Minimum Lethal Dose) for controlling necrotic enteritis disease. Antibody titer elicited by vaccination was measured by toxin neutralization test, ELISA, and challenge test. It revealed that antibody titer expressed by international antitoxin unit per $\mathrm{ml}$ was $7.4,4.1$ and 1.26 respectively according to the mentioned dose, and also the protection percent against challenge was $100 \%$ when vaccinated with either 48 or 96 Minimum Lethal Dose, while it gave $80 \%$ when vaccinated with 24 Minimum Lethal Dose.It concluded that use of Clostridium perfringens alpha Toxoid with recommended dose of 48 MLD able to protect turkey for 6 months.
\end{abstract}

Key words:Alpha toxin, Clostridium perfringens, Turkey, Type A, Vaccine

\section{INTRODUCTION}

Enteric disorders were one of the most important groups of diseases that affect poultry and continuing to cause high economic losses in many areas worldwide due to increased mortality rates, decreased weight gain increased medication costs and increased feed conversion rate. The causal of enteric disorders either pathogens (viruses, bacteria, parasites) as a monocausal due to specific pathogen or synergy with different other microorganisms (multicausal) or non-infectious causes such as feed and /or management related factors. One of the most important pathogens cause severe enteric disorders either mono or multicausal infection is Clostridium perfringens $(C$. perfringens) type $\mathrm{A}$ that causes severe clinical manifestation and lesions include necrotic enteritis; necrotic dermatitis; cholangiohepatitis as well as gizzard erosion in addition it had been indicated to cause food poisoning in human (Lovland and Kaldhusdal, 2001; McClane et al., 2006; Novoa-Garrido et al., 2006). The ban and voluntary withdrawal antibiotics have resulted in resurgence of necrotic enteritis. Moreover, the demands of consumers for antibiotic free poultry products has continued to grow (Mwangi et al., 2018)
The necrotic enteritis can be caused by one or number of predisposing factors such as the high levels of non-starch polysaccharides and fishmeal, pathogenic Clostridium perfringens, and the factors that damage the epithelial cells like fusarium mycotoxin. Previous studies have revealed that different predisposing factors caused similar shifts in intestinal microbiota composition and reduced the abundance when the poultry chickens fed a fishmeal based diet; Eimeria infection, and mycotoxin contaminated diet (Antonissen et al., 2016)

Alpha toxin was one of the most important lethal and dermonecrotic toxins produced by $C$. perfringens, known as phospholipase $C$ (PLC). It was produced in different amounts by all types (A, B, C, D and E) of C. perfringens and was considered as a primary virulence factor involved in clostridial myonecrosis (Williamson and Titball, 1993; Awadet al., 1995). In C. perfringens type A, the alphatoxin was the unique lethal protein produced during vegetative growth. Owing to its role in gas gangrene disease, food poisoning and animal enterotoxemia, $C$. perfringens type A strains, had been the subject of intense investigations over the past 60 years (McDonel, 1980). Alpha-toxin, produced by $C$. perfringens, was a 
metalloenzyme with molecular weight of $43 \mathrm{kDa}$ (Takahashi et al., 1974; Hale and Stiles, 1999) and LD50 of $40 \mathrm{ng} / \mathrm{mL}-1$ (Naylor et al., 1997) and catalyzed the hydrolysis of lecithin and phospholipids (Saint-Joanisetal., 1989; Hale and Stiles, 1999).

A common commensally inhabitant of the healthy broiler chicken gut microflora $C$. perfringens was frequently found in the feces of livestock and poultry at high levels (Tschirdewahn et al., 1991). However, its overgrowth in fowl can be considered an imbalance of the gut ecosystem at the microbial level resulting in gastrointestinal dysbacteriosis and necrotic enteritis (Wages and Opengart, 2003). Poultry necrotic enteritis was associated with predisposing factors (Elwinger et al., 1992) such as Eimeria spp. infections (coccidiosis); the incorporation of dietary fish meal, rye, barley and wheat as major feed components. The withdrawal of dietary subtherapeutic Antibiotic Growth Promotants (AGPs). While the impact of AGP withdrawal on chicken health, welfare and production efficiency had been studied to a limited degree (Casewell et al., 2003), it was known that the exclusion of ionophore coccidiostat antibiotics, which were generally anticlostridial, from the broiler chicken diet had resulted in higher rates of necrotic enteritis in broiler chickens raised in AGP free settings (Elwinger et al., 1992; Elwingeret al., 1998).

Necrotic enteritis is caused by $C$. perfringens type A total has been positively limited by administered antibiotics to the diet of poultry, however recent concerns regarding the influences of this practice on ehancing antibiotic resistance in pathogens of human have led to consider alternative schedules such as vaccination, immune responses against alpha toxin can provide partial protection against Necrotic enteritis (Joseph et al., 2018). So the aim of present study was to prepare of $C$. perfringens alpha toxoid vaccine for controlling the necrotic enteritis disease.

\section{MATERIALS AND METHODS}

\section{Ethical approval}

All procedures performed according to Egyptian ethical standards of the national research committee. Approved from Institutional Animal Care and Use Committee (IACUC) Cairo University under number 1221 $/ 2013$ review and approve all activities involving the use of vertebrate animals prior to their initiation.

\section{Strain}

Clostridium perfringens type A was previously isolated and identified in Anaerobic Bacterial Vaccine
Research Department of Veterinary Serum and Vaccine Research Institute (VSVRI) from turkey farms in Egypt from different localities (Giza, Qalyobia, Ismalia governorates) suffered from necrotic enteritis and high mortalities, the identification of the isolates was depended on culture characters; biochemical tests and serological tests (Nagler Test, Toxin Neutralization test and Dermonecrotic reaction) beside was PCR and DNA sequence (El-Helw et al., 2014).

\section{Vaccine preparation}

The lyophilized strain was rehydrated into cooked meat medium and then inoculated into the primary toxin production medium incubated at $37^{\circ} \mathrm{C}$ for four hours and then transferred into main toxin production medium according to El-Helw et al. (2017) and incubated at $37^{\circ} \mathrm{C}$ for four hours. Then about $10 \mathrm{ml}$ of this culture was taken for determination of Minimum Lethal Dose (MLD) according to Fu et al. (2004) and the rest of culture was inactivated by adding $0.5 \%$ (Formaldehyde 37\%) (v/v) until complete inactivation for 7 days. Microfiltration and ultra-filtration by using millipore ${ }^{\circledR}$ filter was applied for separation of unwanted cells from toxoid and concentration of toxoid. Aluminum hydroxide gel adjuvant was added at $20 \%(\mathrm{v} / \mathrm{v})$ to alpha toxoid and homogenized by using magnetic stirring at room temperature. Sterility and Safety test of the above vaccine was done according to OIE (2016).

\section{poults \\ Evaluation of the prepared vaccine in turkey}

Vaccinal dose. It was adjusted according to MLD to contain different three MLD (96, 48 and 24) per $0.5 \mathrm{ml}$ dose.

Vaccination schedule. Fifty Orlopp Bronze turkey poults aged 4-6 weeks was divided into four groups, the first three groups containing 15 birds in each, and fourth group containing five birds was left as control. Vaccination schedule of these poults was indicated in table 1.

Table 1. Vaccination schedule of Orlopp Bronze turkey at 5 weeks of age

\begin{tabular}{lcll}
\hline Groups & $\begin{array}{c}\text { No. of } \\
\text { turkey/ } \\
\text { group }\end{array}$ & $\begin{array}{l}\text { Dose /Rout of } \\
\text { Injection }\end{array}$ & Booster dose \\
\hline 1 & 15 & $96 \mathrm{MLD} / 0.5 \mathrm{ml}, \mathrm{I} / \mathrm{M}$ & It was done in all birds \\
2 & 15 & $48 \mathrm{MLD} / 0.5 \mathrm{ml}, \mathrm{I} / \mathrm{M}$ & $\begin{array}{l}\text { with the same dose and } \\
\text { route after } 21 \text { days from } \\
\text { first vaccine in each } \\
\text { group }\end{array}$ \\
3 & 15 & $24 \mathrm{MLD} / 0.5 \mathrm{ml}, \mathrm{I} / \mathrm{M}$ \\
$\mathrm{U}^{*}$ (Control) & 5 & $\begin{array}{l}0.5 \mathrm{ml} \text { saline for each } \\
\text { bird }\end{array}$ & \\
\hline No: Number, MLD: Minimum Lethal Dose, U*. Unvaccinated
\end{tabular}

No: Number, MLD: Minimum Lethal Dose, $\mathrm{U}^{*}:$ Unvaccinated 
Blood samples were taken after two weeks from second dose, and then every month for six months, serum were collected and stored at $-20^{\circ} \mathrm{C}$ until evaluation of antibody titers.

\section{Determination of antibody titer}

Toxin neutralization test. It was done according to Barile et al. (1970) firstly $\mathrm{L}+/ 2$ dose of alpha toxin of $C$. perfringens type $\mathrm{A}$ determined and after that serum samples were serially diluted and equal volume of alpha toxin dose $(\mathrm{L}+/ 2)$ was added for each dilution then the mixture was incubated at $37^{\circ} \mathrm{C}$ for one hour two mice were injected from each dilution with $0.2 \mathrm{ml} \mathrm{I} / \mathrm{V}$ and observed for 24 hours. The reciprocal of the highest dilution of serum that cause death of all mice multiplied by two was regarding as the antibody titer which expressed by International Unit (IU).

ELISA. It was done according to Lee et al. (2012) and antibody titer was calculated against standard curve by weighted parallel linear regression according to Grabowska et al. (2002) according to equation:

$$
\mathrm{U}_{\mathrm{s}}=\mathrm{U}_{\mathrm{R}} \mathrm{Df}^{\mathrm{D}}
$$

Were

$\mathrm{U}_{\mathrm{R}}$ : number of units in reference serum and Us: number of units of serum samples; D: horizontal distance between the sample and reference line; Df: dilution factor (equal to 2 were used twofold dilution).

The estimated slope in the new weighted Parallel Linear Line slop for both sample and reference

$b_{\mathrm{wPLL}}=\left(\mathrm{S}_{\mathrm{XYs}}+\mathrm{S}_{\mathrm{XYR}}\right) /\left(\mathrm{S}_{\mathrm{XXs}}+\mathrm{S}_{\mathrm{XXR}}\right)$ and the horizontal distance, $\mathrm{D}$ was then

$$
\mathrm{D}=\mathrm{X}_{\mathrm{S}}-\mathrm{X}_{\mathrm{R}}-\frac{(Y s-Y R)}{\text { bwPLL }}
$$

1- Hemolysin Inhibition Assay it was done according to Jayappa et al. (2006) serial twofold dilution from serum samples were made in $\mathrm{v}$ bottom microtiter plate, $100 \mu$ of four hemolysin unit of alpha toxin was added to each well. The plates were incubated at $36^{\circ} \mathrm{C}$ for one hour, then $100 \mu \mathrm{l}$ of $0.5 \%$ of sheep Red Blood cells added to each well and incubated at $36^{\circ} \mathrm{C}$ for three hours

The reciprocal of the highest dilution of tested sample that indicated no hemolysis was considered the endpoint.

2- Challenge test was done according to Kaldhusdal and Hofshagen (1992). In brief the lyophilized strain of $C$. perfringens was reconstituted into cooked meat medium and serially subculture into fluid Thioglycollate broth medium increasing the volume at each step to reach volume $(1 \mathrm{~L})$, this culture was mixed with feed in a ratio of three parts cultures, four parts of high protein feed. The mixture which had a paste like consistency was placed in feed tray and to birds.

Five birds from each vaccinated groups (one, two and three) and three from control unvaccinated group were fed on the previous mentioned culture with feed for four successive days, two weeks after second vaccination. Birds were observed for presence of any clinical signs of necrotic enteritis. These birds were slaughtered and score of lesions were determined (0-4) where 0: No lesion; $1+$ : friable small intestine; 2+: Focal necrosis; 3+: large patches of necrosis, and 4+: severe necrosis.

The challenge test was repeated after six months of second dose of vaccination as the same first one.

\section{Statistical analysis}

All statistical analyses were performed with Easy R in Saitama Medical Center, Jichi Medical University, Japan .21) One-way ANOVA followed by the Tukey's test was used to evaluate differences among three or more groups. Differences were considered to be significant for values of $\mathrm{p}<0.05$.

\section{RESULTS}

Clostridium perfringens type A, the alpha-toxin is the unique lethal protein produced during vegetative growth at logarithmic phase, at this study the toxin production medium that used produce alpha toxin at $120 \mathrm{MLD} / \mathrm{ml}$ and then submitted to microfiltration by using Millipore ${ }^{\circledR}$ filter $(0.22 \mu \mathrm{m})$ for clarification of alpha Toxoid and then using Millipore ${ }^{\circledR}$ ultrafiltration (10000 $\mathrm{n}$ mol. w.) was one of the first author to employ high-pressure ultrafiltration to obtain alpha-toxin in high concentration, the efficiency of high-pressure ultrafiltration for purification of alpha-toxin was evaluated the ultrafiltration process was less time-consuming, easier to perform and less laborious than ammonium sulfate and acetone precipitations. So after ultrafiltration of alpha Toxoid made double fold concentration to achieved $240 \mathrm{MLD} / \mathrm{ml}$, so the group one vaccinated with dose one after addition of aluminum hydroxide gel as adjuvant containing 96 MLD/0.5 ml; group two vaccinated with dose two the origin was double fold dilution so it containing 48 MLD $/ 0.5 \mathrm{ml}$, and group three vaccinated with dose three dilution of origin $1 / 4$ so it containing $24 \mathrm{MLD} / \mathrm{ml}$.

Antibody titers in sera of vaccinated turkey in groups one and two as indicated in table 2 revealed that the mean antibody titer was $7.4 \mathrm{IU} / \mathrm{ml}$ and $4.13 \mathrm{IU} / \mathrm{ml}$ respectively. While in group three received dose 24 MLD the antibody titer was $1.26 \mathrm{IU} / \mathrm{ml}$. Antibody titer in sera of vaccinated 
bird measured by ELISA which calculated according to linear regression fit where the standard serum of known titer measured by TNT used against unknown serum, the coefficient of variance was 0.9983 and the intercept (0.3165), slop (0.584).

Mean Antibody titer measured by ELISA in group one was $8.04 \mathrm{U} / \mathrm{ml}$ which came in parallel with Toxin Neutralization Test (TNT) $7.4 \mathrm{IU} / \mathrm{ml}$, there was no significantly difference $(\mathrm{P}>0.05)$, but in groups two and three the mean antibody titer measured by ELISA were (4.83 and $1.78 \mathrm{u} / \mathrm{ml}$ ) respectively had a significant difference $(\mathrm{P}<0.05)$ with results obtained by TNT. These results were due to high sensitivity of ELISA for measurement of antibody titer especially in a low level.

Geometric mean titer of antibodies measured by hemolysin Inhibition assay revealed that in Group one vaccinated with $96 \mathrm{MLD} /$ dose was $1176.26 \mathrm{HU}$, Group two vaccinated with $48 \mathrm{MLD} /$ dose was 466.8 , and in Group three vaccinated with $24 \mathrm{MLD} /$ dose was 25.39 . Challenge test for vaccinated turkey and control after two weeks of second dose revealed that in group one and two the vaccine gave $100 \%$ protection for all birds against challenge and the average score lesions was 0 . But in group three vaccinated with 24 MLD dose gave $80 \%$ protection and score lesions was 0.4 . These results were parallel with antibody titers which cover the permissible level required for vaccine release, but in group three after six months post vaccination repeat challenge test on present birds revealed that protection became only $10 \%$ and score lesion where three, but in groups one and two antibody titer was one and $0.5 \mathrm{IU} / \mathrm{ml}$ and protection $\%$ $(60 \%)$, score lesions $(1,1.4$ respectively), so from these results revealed that group two vaccinated with $48 \mathrm{MLD} /$ dose able to cover the permissible level of antibody titer required for release the vaccine and able to maintained the antibody titer and protection of birds for six months so it could be recommended for revaccination of birds after six months when used this birds as breeder but for broiler farms only vaccination on two weeks with two doses 21 days apart.

\section{Duration of immunity in vaccinated turkey}

As indicated in group one there was a gradual rise in antibody titer after two weeks of post second dose of vaccination were reach to 9IU, $10.2 \mathrm{EU}$ and $2048 \mathrm{HU}$ measured by TNT; ELISA, and Hemolysin Unit respectively (Table 4). After two months, then gradual decrease in antibody titer from three months to six months after vaccination where reach to $1 \mathrm{IU}, 1.56 \mathrm{EU}$ and 50.5 $\mathrm{HU}$ and in group two the antibody titer reach to $0.5 \mathrm{IU}, 0.8$ $\mathrm{EU}$ and $32 \mathrm{HU}$, while in group three antibody titer was 0.2 IU, $0.28 \mathrm{EU}$ and $22 \mathrm{HU}$. Also as indicated in table five the challenge test was done in vaccinated turkey after six months revealed that in group one and two the protection rate was $60 \%$, while in group three it was $10 \%$.

Table 2. Antibody titer in sera of vaccinated turkey after 2 weeks past of second doses

\begin{tabular}{|c|c|c|c|c|c|c|c|c|c|}
\hline $\begin{array}{l}\text { Bird } \\
\text { No. }\end{array}$ & \multicolumn{3}{|c|}{$\begin{array}{c}\text { Vaccinated with } 96 \mathrm{MLD} / 0.5 \mathrm{ml} \\
\text { (Group 1) }\end{array}$} & \multicolumn{3}{|c|}{$\begin{array}{c}\text { Vaccinated with } 48 \text { MLD/0.5 ml } \\
\text { (Group 2) }\end{array}$} & \multicolumn{3}{|c|}{$\begin{array}{c}\text { Vaccinated with } 24 \text { MLD/0.5 ml } \\
\text { (Group 3) }\end{array}$} \\
\hline 2 & 8 & 9.45 & 2048 & 4 & 4.78 & 512 & 1 & 1.77 & 32 \\
\hline 3 & 8 & 10.02 & 1024 & 4 & 4.55 & 64 & 1 & 1.89 & 16 \\
\hline 4 & 6 & 5.88 & 512 & 4 & 3.87 & 128 & 1 & 1.94 & 16 \\
\hline 7 & 8 & 8.12 & 1024 & 4 & 4.12 & 1024 & 2 & 2.45 & 16 \\
\hline 8 & 8 & 7.99 & 1024 & 4 & 5.09 & 1024 & 1 & 1.67 & 16 \\
\hline 9 & 9 & 9.47 & 2048 & 4 & 4.89 & 512 & 1 & 1.83 & 16 \\
\hline 10 & 6 & 6.94 & 1024 & 4 & 5.3 & 1024 & 2 & 2.09 & 64 \\
\hline 11 & 8 & 8.23 & 2048 & 5 & 5.99 & 1024 & 2 & 2.33 & 32 \\
\hline Mean & $7.4 \pm 1.08$ & $8.04 \pm 1.2$ & 1178.2 & $4.13 \pm 0.33$ & $4.83 \pm 0.5$ & 466.8 & $1.26 \pm 0.44$ & $1.78 \pm 0.3$ & 25.3 \\
\hline $\begin{array}{l}\text { Control } \\
\text { group }\end{array}$ & 0 & 0 & 0 & 0 & & & & & \\
\hline
\end{tabular}


Table 3. Response of vaccinated Orlopp Bronze turkey aged 5 weeks to challenge with $C$. perfringens two weeks after second dose of vaccination

\begin{tabular}{lccc}
\hline Treatment & $\begin{array}{c}\text { No. of birds with } \\
\text { gross lesion (\%) }\end{array}$ & $\begin{array}{c}\text { Average lesion } \\
\text { score }\end{array}$ & $\begin{array}{c}\text { Protection } \\
(\%)\end{array}$ \\
\hline Vaccinated with 96 MLD (Group1) & $0 / 5(0 \%)$ & 0 & 100 \\
Vaccinated with 48 MLD (Group2) & $0 / 5(0 \%)$ & 0 & 100 \\
Vaccinated with 24 MLD (Group3) & $1 / 5(20 \%)$ & 0.4 & 80 \\
Non vaccinated, challenged & $3 / 3(100 \%)$ & 3.33 & - \\
\hline
\end{tabular}

No: Number, MLD: Minimum Lethal Dose

Table 4. Duration of antibody titer measured by TNT and ELISA, and hemolysin inhibition assay expressed by hemolysin unit in sera of vaccinated Orlopp Bronze turkey aged 5 weeks against necrotic enteritis

\begin{tabular}{|c|c|c|c|c|c|c|c|c|c|}
\hline \multirow{2}{*}{$\begin{array}{l}\text { After second } \\
\text { dose of } \\
\text { vaccination }\end{array}$} & \multicolumn{3}{|c|}{ GROUP (1) } & \multicolumn{3}{|c|}{ GROUP (2) } & \multicolumn{3}{|c|}{ GROUP (3) } \\
\hline & $\begin{array}{l}\text { TNT } \\
\text { (IU) }\end{array}$ & ELISA & $\begin{array}{c}\text { Hemolysin } \\
\text { Unit }\end{array}$ & $\begin{array}{l}\text { TNT } \\
\text { (IU) }\end{array}$ & ELISA & $\begin{array}{c}\text { Hemolysin } \\
\text { Unit }\end{array}$ & $\begin{array}{c}\text { TNT( } \\
\text { IU) }\end{array}$ & ELISA & $\begin{array}{c}\text { Hemolysin } \\
\text { Unit }\end{array}$ \\
\hline 1 month & 8.3 & 9.23 & 2048 & 5 & 5.89 & 560 & 2.5 & 3.09 & 288 \\
\hline 2 month & 9 & 10.2 & 2048 & 6 & 6.48 & 670 & 3.5 & 4.22 & 388 \\
\hline 3 month & 6 & 6.95 & 1020 & 4 & 4.78 & 465 & 2 & 2.66 & 64 \\
\hline 4 month & 4 & 5.22 & 461.2 & 2 & 2.77 & 130 & 1 & 1.44 & 40 \\
\hline 5 month & 3 & 3.96 & 382 & 2 & 2.49 & 125 & 0.5 & 0.89 & 30 \\
\hline 6 month & 1 & 1.56 & 50.5 & 0.5 & 0.8 & 32 & 0.2 & 0.28 & 22 \\
\hline 7 month & 0.3 & 0.366 & 24 & 0.2 & 0.19 & 15.5 & 0.1 & 0.16 & 10 \\
\hline
\end{tabular}

TNT: Toxin Neutralization Test, ELISA: Enzyme Linked Immunosorbant Assay, IU: International Unit

Table 5. Response of vaccinated Orlopp Bronze turkey aged 5 weeks to challenge with $C$. perfringens after six months of post vaccination

\begin{tabular}{lccc}
\multicolumn{1}{c}{ Treatment } & No.* of birds with gross & Average lesion & Protection \\
score & lesion (\%) & 1 & 6 \\
\hline Group (1) vaccinated with 96 MLD & $2 / 5(40 \%)$ & 1.4 & 60 \\
Group (2) vaccinated with 48 MLD & $2 / 5(40 \%)$ & 3 & 60 \\
Group (3) vaccinated with 24 MLD** & $4 / 5(90 \%)$ & 3.33 & 10 \\
Non vaccinated, challenged & $3 / 3(100 \%)$ & 0 \\
\hline
\end{tabular}

*No: number, **MLD: minimum lethal dose

\section{DISCUSSION}

Clostridium perfringensis the most important cause of clostridial enteritis in domesticanimals. In broilerchickens, C. perfringens has been known for decades as apathogen responsible for necrotic enteritis (NE), hepatitis, and cholecystitis. NE exists in a clinical form with severeoutbreaks and mortality and a subclinical form, which wasmainly characterized by a reduced growth rate and anincreased condemnation rate. C. perfringens was member of the normal intestinal microflora in poultry and consequently, the mere presence of this bacterium in the intestine was not sufficient to provoke disease; this happens only when high numbers were present. A number of predisposing factors had been identified, among them high wheat, barley or fish meal contents in the feed, and an underlying coccidiosis problem.
Necrotic enteritis via of proliferations of Clostridium perfringens type $\mathrm{A}$ and associated toxins in the small intestine of birds can be a harmful enteric disease which cause unexpected mortality, sudden diarrhea and mucosal necrosis. It also has contributed to high economic losses in global poultry industry (Yang et al., 2019)

An important defense system that constantly utilized and trigger was the adaptive immune system through application of vaccines. Vaccines had proven to be effective tools to prevent or lessen the impact of diseases which biosecurity alone cannot prevent. However, it needed to realized that many of vaccines caused do cause a transient immunosuppression and that all label claims clearly state that "only healthy animals should be vaccinated. So problems could occur when a flock was going through an undetected subclinical challenge and a vaccine was applied. The vaccine may either precipitate 
clinical disease or the vaccine is unable to work leaving the flock vulnerable to future challenge by that pathogen. The other essential consideration is the timing between vaccinations or between vaccination and a major stressor such as moving the flock from brooding to the finishing barns. For example, flocks that were vaccinated for Hemorrhagic Enteritis Virus (HEV) and then moved one week later may become ill, because major stressors (maximum vaccine replication and moving to a new environment, especially during the winter months) had coincided.

So this result pass in parallel with previous result of (Elham et al., 2014) in which they using a fixed dose (60 $\mathrm{MLD} / \mathrm{ml}$ ) for vaccination of rabbits against rabbit clostridial enterotoxaemia and the antibody titer was 5 $\mathrm{IU} / \mathrm{ml}$, and this titer was over the permissible limits (4 $\mathrm{IU} / \mathrm{ml}$ ) according to United States Department of Agriculture (USDA) (2002), which surpass requirements to receive a conditional license pass standardized test by the development of a serum antibody concentration of at least four international antitoxin units per $\mathrm{ml}$ in at least 80 $\%$ of vaccinated animals that were seronegative prior to vaccination. These findings agree with Garcia-Moreira et al. (2016) that prepared recombinant trivalent vaccine containing epsilon, alpha and beta using $\mathrm{Al}(\mathrm{OH})_{3}$ adding $200 \mu \mathrm{g}$ of each of the three antigens of the vaccine can induce $5.19 \mathrm{IU} / \mathrm{ml}$ for alpha toxin, thus there was a similarity for determination a fixed dose of antigen to be added to the vaccine either minimum lethal dose of toxin or protein concentration. From the above result it could be concluded that used of 48 MLD /Dose for turkey in vaccine preparation was enough for coverage the permissible limit required for approved vaccine.

There was parallel between antibody titer measured by TNT; ELISA, and hemolysin assay approved by several authors report the efficiency of the ELISA technique in the quantification of vaccine antigens. However, as this study demonstrated, and calculated by weighted parallel linear regression for accurate calculation of antibody titer. For instance, the sandwich ELISA (El-Idrissi and Ward, 1992a, 1992b), was capable of detecting, in a linear form, concentrations between 7.8 and $125 \mathrm{ng} / \mathrm{mL}$ and the minimum detectable $2 \mathrm{ng} / \mathrm{mL}$. Nagahama et al. (1991) reported that the sensitivity of ELISA with specific antibodies for the detection of beta, epsilon and iota toxins of $C$. perfringens may reach up to $1.0 \mathrm{mg} / \mathrm{mL}$ for the purified iota and beta toxins and $0.1 \mathrm{ng} / \mathrm{mL}$ of purified epsilon toxin. (Uzal et al., 2003) reported the detection of $0.075 \mathrm{DL} 50 / \mathrm{mL}$ of epsilon toxin in the intestinal content. By comparing the sandwich ELISA and the serum neutralization for the detection of beta and epsilon toxin in intestine content, a study found a sensibility and specificity of $90.5 \%$ and $89.2 \%$ for the beta toxin and 97.4 and 95.6 for the epsilon toxin (El-Idrissi and Ward, 1992a and 1992b). On the other hand, this study indicated promising results when utilizing the indirect ELISA measured by linear regression.

The results of challenge test revealed that $40 \%$ of turkey in groups one and two developed necrotic enteritis lesion when challenged with virulent strain of Clostridium perfringens type A after 6 months post vaccination with $0.5 \mathrm{IU} / \mathrm{ml}$ antibody titer, while in group three $90 \%$ of vaccinated turkey had lesions of necrotic enteritis associated with antibody titer below $0.5 \mathrm{IU} / \mathrm{ml}$ so the protection of intestine and resist to challenge and developed of lesions depend on immunity of gut by vaccination and production of antibodies and also by presence of gut miroflora as mentioned by Keerqin et al. (2017) that found miroflora play an important role in protecting poultry from necrotic enteritis infection where both ileal and cecal inoculants containing Lactobacillus spp. are widely regarded as beneficial bacteria in poultry.

The duration of immunity in vaccinated turkey revealed that there was a relation between antibody titer in sera of vaccinated turkey and protection against challenge test were the antibody titer of $0.5 \mathrm{IU} / \mathrm{ml}$ sufficient to made protection up to $60 \%$, this relation achieved by lovland et al. (2004) use toxoids vaccines based on $C$. perfringens type $\mathrm{A}$ and $\mathrm{C}$ toxoids to vaccinate breederflocks. The IgG responses in vaccinated parent hens weredistinct and the levels of antibodies to $C$. perfringens alpha - toxin in progeny of the vaccinated hens was highenough to protect the progeny against subclinical $C$. perfringens associated necrotic enteritis. Also, Heier et al. (2001) provided that active and passive immunity using vaccination against $C$. perfringens and its toxins appears to offer protection. Found out that broiler flocks with high titers of maternal antibodies against $C$. perfringens alpha-toxin had lower mortality during the production period than flocks with low tiers.

\section{CONCLUSION}

It concluded that a vaccine comprising of Clostridium perfringens alpha Toxoid wherein containing 48 MLD/Dose was sufficient to elicit at least $4 \mathrm{IU} / \mathrm{ml}$ antialpha toxin antibody in vaccinated turkey which was sufficient for protect turkey for six months. There was linear parallel between antibody titer measured by Toxin Neutralization Test; ELISA, and Hemolysin Inhibition 
Test so for evaluation of further recent batches of vaccine can be used either ELISA or Hemolysin Inhibition Test as test replacement of TNT for limitation used of mice. And also from economic point of view it better for control of necrotic enteritis disease in turkey flock used the vaccine to subside used of antibiotic as food additive which cause risk of antibiotic resistance for human.

\section{DECLARATIONS}

\section{Competing interests}

All authors have no conflict of interest.

\section{Consent to publish}

The author(s) grant(s) the publisher the sole and exclusive license of the full copyright in the contribution. Consequently, the publisher shall have the exclusive right throughout the world to publish and sell the contribution in all languages and all other forms of electronic publication.

\section{Author's contribution}

Elham El-sergany and El-Helw Hamed prepared and evaluated Necrotic enteritis vaccine; Hala El-Sawy vaccinated turkey and taken blood samples; Taha Medhat and Abdalla Yasser writing the paper and made statistical analysis, and El-Meneisy Alaa reviewed the article.

\section{REFERENCES}

Antonissen G, Eeckaut V, Van Driessche K, Onrust L, Haesebrouck F, Ducatelle R, Moore RJ and Van Immerseel F (2016). Microbial shifts associated with necrotic enteritis. Avian Pathology, 45 (3): 308-312. DOI:http://doi.org/10.1080/03079457.2016.1152625.

Awad MM, Bryant AE, Stevens DL and Rood JI (1995). Virulence studies on chromosomal alpha-toxin and thetatoxin mutants constructed by allelic exchange provide genetic evidence for the essential role of alpha-toxin in Clostridium perfringens-mediated gas gangrene. Molecular Microbiology, 15:191-202. DOI:10.1111/j.1365-2958. 1995.tb02234.x

Barile MF, Hardegree MC and Pittman M (1970). Immunization against neonatal tetanus in New Guinea. 3 The toxinneutralization test and the response of guinea pigs to the toxoids as used in the immunization schedules in New Guinea. Bull. WHO, (43): 453-459.

Casewell M, Friis C, Marco E, McMullin P and Phillips I (2003). The European ban on growth-promoting antibiotics and emerging consequences for human and animal health. Journal Antimicrobial Chemotherapy, 52:159-161.DOI: 10.1093/jac/dkg313

EL-Idrissi AH and Ward GE (1992a). Development of double sandwich ELISA for Clostridium perfringens beta and epsilon toxins. Veterinary Microbiology, 31 (1):89-99. DOI:10.1016/0378-1135(92)90144-I
EL-Idrissi AH and Ward GE (1992b). Evaluation of enzymelinked immunosorbent assay for diagnosis of Clostridium perfringens enterotoxemias. Veterinary Microbiology, 31 (4): 389-396. DOI:10.1016/0378-1135(92)90131-C

Elham F. El-Sergany, Taha MM, El-Helw HA and Hala El-Sawy (2014). Effect of using different antifoams on toxin production of clostridium perfringens type A. Benha Veterinary Medical Journal, 27 (1):1-7.

El-Helw HA, Elham F El-Sergany, Abdalla YA, Taha MM, Abdella IL and El-Meneisy AA (2014). Role of Clostridium perfringens type $\mathrm{A}$ as a causative agent of necrotic enteritis in Turkey. Veterinary Medical Journal, 60 (2): 1-22.

El-Helw HA, Elham F. El-Sergany, Hussein AS, Taha MM, Abdalla YA and El-Meneisy AA (2017). Study some factors affecting on Clostridium perfringens type A alpha toxin production. Animal Health Research Journal, 5 (4): 510-520.

Elwinger K, Berndtson E, Engstrom B, Fossum $\mathrm{O}$ and Waldenstedt L (1998). Effect of antibiotic growth promoters and anticoccidials on growth of Clostridium perfringens in the caeca and on performance of broiler chickens. ActaVeterinaria Scandinavica, 39:433-441.

Elwinger K, Schneitz C, Berndtson E, Fossum O, Teglof B and Engstom B (1992). Factors affecting the incidence of necrotic enteritis, caecal carriage of Clostridium perfringens and bird performance in broiler chicks. ActaVeterinaria Scandinavica, 33:369-378.

Fu SW, Xue J, Zhang YL and Zhou DY (2004). Simplified purification method for Clostridium difficile toxin A. World Journal Gastroenterol, 10(18): 27562758.DOI: 10.3748/wjg.v10.i18.2756.

Garcia-Moreira GMS, Salvarani FM, Pouey da Cunha CE, Mendonca M, Moreira AN, Goncalves LA, Pires PS, Lobato FCF and Conceicao FR (2016). Immunogenicity of a trivalent recombinant vaccine against Clostridium perfringens alpha, beta and epsilon toxins in farm ruminants. Scientific reports, 6: 22816. DOI: 10.1038/SREP22816.

Grabowska K, Wang X, Jacobsson A and Dillner J (2002). Evaluation of cost-precision rations of different strategies for ELISA measurement of serum antibody levels. Journal of Immunological Methods, 271: 1-15. DOI: 10.1016/S0022-1759(02)00334-4

Hale ML and Stiles BG (1999). Detection of Clostridium perfringens alpha toxin using a capture antibody ELISA. Toxicon, 37: 471-84. DOI: $10.1016 /$ S00410101(98)00179-2

Heier BT, Lovland A, Soleim KB, Kaldhusdal M and Jarp J (2001). A field study of naturally occurring specific antibodies against Clostridium perfringens alpha toxin in Norwegian broiler flocks. Avian Disease, 45: 724-732. DOI: $10.2307 / 1592919$.

Jayappa H, Omaha NE and O`Connell K (2006). C. perfringens alpha Toxoid vaccine. United States Patent Pub. No. US. 2006/0233825A1.

Joseph G, Hunter L, Shyra W, Amanda MT, Horsman J, Miranda Y, Diamos AG, Roland KL and Hason HS (2018). Evaluation of a toxoid fusion protein vaccine produced in 
plants to protect poultry against necrotic enteritis. Peerj Preprints.

DOI:https://doi.org/10.7287/Peerj.Prepraints.27390v1.

Kaldhusdal M and Hofshagen M (1992). Barley inclusion and avoparcin supplementation in broiler diets. 2. Clinical, pathological, and bacteriological findings in a mild form of necrotic enteritis. Poultry Science,71 (7): 1145-1153. DOI: 10.3382/ps.0711145

Keerqin C, Morgan NK, Wu SB, Svihus B and Choct M (2017). Reintroduction of microflora from necrotic enteritisresistant chickens reduces gross lesions and improves performance of necrotic enteritis- challenged broilers. Journal of Applied Poultry Research 26: 449-457. DOI:http://dx.doi.org/10.3382/japr/pfx015.

Lee KW, Lillehoj HS, Park MS, Jang SI, Ritter GD, Hong YH, Jeong W, Jeoung HY, An DJ and Lillehoj EP (2012). Clostridium perfringens alpha-toxin and NetB toxin antibodies and their possible role in protection against necrotic enteritis and gangrenous dermatitis in broiler chickens, 2012, 56(1):230-233. DOI: 10.1637/9847070711-ResNote.1.

Lovland A and Kaldhusdal M (2001). Severely impaired production performance in broiler flocks with high incidence of Clostridium perfringens-associated hepatitis. Avian Pathology,30: 73-81. DOI: 10.1080/03079450020023230.

Lovland A, Kaldhusdal M, Redhead K, Skjerve E and Lillehaug A (2004). Maternal vaccination against subclinical necrotic enteritis in broilers. Avian Pathology, 33: 81-90. DOI: 10.1080/0379450310001636255.

McClane BA, Uzal FA, Miyakawa MF, Lyerly D and Wilkins TD (2006). The Enterotoxic Clostridia. In: Dworkin M., Falkow S., Rosenberg E., Schleifer KH., Stackebrandt E. (eds) The Prokaryotes. Springer, New York, NY, USA, pp. 688-752.

McDonel JL (1980). Clostridium perfringens toxins (type A, B, C, D, E).Pharmacology \& Therapeutics, 10: 617-655.

Naylor RD, Martin PK and Barker LT (1997). Detection of Clostridium perfringens alpha toxin by enzyme-linked immunosorbent assay, Research Veterinary Science. 63(1):101-102.

Mwangi S, Timmons J, Fitz-coy S and Parveen S (2018). Characterization of Clostridium perfringens recovered from broiler chicken affected by necrotic enteritis. Poultry Science, $98 \quad$ (1):128-135. DOI:http://dx.doi.org/10.3382/ps/pey332.

Nagahama M, Kobayashi K, Ochi S and Sakurai J (1991). Enzyme-linked immunosorbent assay for rapid detection of toxins from Clostridium perfringens. FEMS Microbiol. Lett, 68:41-44.
Novoa-Garrido M, Larsen S and Kaldhusdal M (2006). Association between gizzard lesions and increased caecal Clostridium perfringens counts in broiler chickens. Avian Pathology, 35(5): 367-372. DOI: $10.1080 / 03079450600924150$

Odendaal MW. (1987). Purification of the alpha toxin of Clostridium perfringens type A by ultra-filtration and gel chromatography. Onderstepoort Journal of Veterinary Research, (54): 39- 43.

The World Organisation for Animal Health (OIE), Terrestrial Manual (2016). Tests for sterility and freedom from contamination of biological materials. Chapter 1.1.9, pp. 105-114.

Saint-Joanis B, Garnier T and Cole ST (1989). Gene cloning shows the alpha-toxin of Clostridium perfringens to contain both sphingomyelinase and lecithinase activities. Molecular Genetics, 219(3): 453-460. DOI: 10.1007/BF00259619.

Stephen J (1961). The isolation of the alpha-toxin of C. welchii type A by zone electrophoresis in vertical columns.Biochemical Journal, (80): 578-584. DOI: 10.1042/bj0800578.

Takahashi T, Sugahara T and Ohsaka A(1974). Purification of Clostridium perfringens phospholipase $\mathrm{C}$ (alpha-toxin) by affinity chromatography on agarose-linked egg-yolk lipoprotein. Biochim Biophys Acta, 351(1):155-171. DOI: 10.1016/0005-2744(73)90200-3.

Tschirdewahn B, Notermans S, Wernars K and Untermann F (1991). The presence of enterotoxigenic Clostridium perfringens strains in feces of various animals. International Journal of Food Microbiology, 14:175-178. DOI: 14:175-178. 10.1016/0168-1605(91)90105-X.

Uzal FA, Kelly WR and Thomas R (2003). Comparison of four techniques for the detection of Clostridium perfringens type D epsilon toxin in intestinal contents and other body fluids of sheep and goats. Journal Veterinary Diagnostic Investigation, 15:94-99.

DOI: $10.1177 / 104063870301500202$.

Wages DP and Opengart K (2003). Necrotic enteritis, In Y. M. Siaf (ed.), Diseases of poultry, 11th edition. Iowa State University Press, Ames, Iowa, pp. 781-783.

Williamson ED and Titball RW (1993). A genetically engineered vaccine against the alpha-toxin of Clostridium perfringens protects mice against experimental gas gangrene. Vaccine, 11: 1253-1258. DOI: 10.1016/0264-410X(93)90051-X.

Yang WY, Lee Y, Lu H, Chou CH and Wang C (2019). Analysis of gut microbiota and the effect of lauric acid against necrotic enteritis in Clostridium perfringens and Eimeria side-by-side challenge model. PLoS ONE, 14 (5): e0205784.DOI:https://doi.org/10.1371/journal.pone.02057 84. 